\title{
Author Correction: Optimizing the fragment complementation of APEX2 for detection of specific protein-protein interactions in live cells
}

\author{
Miaomiao Xue ${ }^{1,2}$, Junjie Hou ${ }^{1}$, Linlin Wang ${ }^{1,2}$, Dongwan Cheng ${ }^{1}$, Jingze Lu ${ }^{1}$, Li Zheng ${ }^{1}$ \& \\ Tao Xu iD $^{1,2}$
}

Correction to: Scientific Reports https://doi.org/10.1038/s41598-017-12365-9, published online 27 September 2017

In the original version of this Article, Affiliations 1 and 2 were not listed in the correct order. The correct affiliations are listed below:

Affiliation 1

National Laboratory of Biomacromolecules, CAS Center for Excellence in Biomacromolecules, Institute of Biophysics, Chinese Academy of Sciences, Beijing, 100101, China.

Affiliation 2

College of Life Sciences, University of Chinese Academy of Sciences, Beijing, 100049, China.

This error has now been corrected in the PDF and HTML versions of the Article and in the supplementary information.

(i) Open Access This article is licensed under a Creative Commons Attribution 4.0 International cc. License, which permits use, sharing, adaptation, distribution and reproduction in any medium or format, as long as you give appropriate credit to the original author(s) and the source, provide a link to the Creative Commons license, and indicate if changes were made. The images or other third party material in this article are included in the article's Creative Commons license, unless indicated otherwise in a credit line to the material. If material is not included in the article's Creative Commons license and your intended use is not permitted by statutory regulation or exceeds the permitted use, you will need to obtain permission directly from the copyright holder. To view a copy of this license, visit http://creativecommons.org/licenses/by/4.0/.

(C) The Author(s) 2018

\footnotetext{
${ }^{1}$ National Laboratory of Biomacromolecules, CAS Center for Excellence in Biomacromolecules, Institute of Biophysics, Chinese Academy of Sciences, Beijing, 100101, China. ${ }^{2}$ College of Life Sciences, University of Chinese Academy of Sciences, Beijing, 100049, China. Miaomiao Xue and Junjie Hou contributed equally to this work. Correspondence and requests for materials should be addressed to L.Z. (email: zhengli@ibp.ac.cn) or T.X. (email: xutao@ibp.ac.cn)
} 